\title{
Young doctors' views on their undergraduate child health teaching
}

\author{
A WATERSTON \\ Department of Child Health. Ninewells Hospital and Medical School, Dundee
}

SUMMARY Fifty three recently qualified doctors working in various fields of child health were asked to relate their present work to the teaching they received as undergraduates. A rating scale was used that indicated the doctor's perceptions of the present importance of a subject and the previous deficiency in teaching. History taking and examination techniques were thought to have been adequately taught, but the diagnosis and management of 'minor ailments' in children were thought to have been deficient in the course, despite their importance in present work. A greater emphasis on problem based teaching would make up for this deficiency.

The relation between what is taught to the undergraduate student and the work content of the practising doctor has been studied little and there is disagreement among medical teachers about the closeness of the relation. Some teachers consider that the aim of undergraduate instruction is to educate students and provide the foundation for clinical work and that detailed training in particular skills will only come later. Others feel that the undergraduate will learn better if he or she studies the subject in a more applied way and indeed should aim at competency in some of the important medical skills.

All will probably agree that child health undergraduate teaching should emphasise those aspects of practice that are important to doctors working with children. Meadow, in his 1978 study of students' retrospective assessments of their teaching, tried to find out whether students changed their views of their course after some years in practice, but the doctors were not asked to discuss what contribution their teaching made to the child health components of their practice. ${ }^{1}$ In the present study the aim was to relate young doctors' assessments of the child health requirements of their present work to the undergraduate teaching of the same topics or, in other words, how relevant was the course to their needs?

\section{Subjects and methods}

The method used was similar to that described in a study on the training of pharmacists. ${ }^{2}$ It consisted of the administration of a questionnaire to recently qualified doctors working in various fields of paediatrics.

The doctors interviewed were (1) senior house officers who were in their first six months in hospital paediatrics, (2) senior house officers who were in a six month rotation as hospital casualty officers, and (3) trainee general practitioners who were in the first six months of their traineeship period (some of these had previous hospital experience in paediatrics). All the doctors were working in Tayside and represented all those who filled the above posts during the study. Twenty three senior house officers and 30) trainee general practitioners were interviewed either by the author or a research assistant.

The doctors were initially asked an open ended question: 'Do you think that there are any particular areas in child health which you feel to be especially important in your present job, which were inadequately taught at your medical school?'. Each was asked to expand on this question in an informal way.

A questionnaire was then administered that related to particular content areas in child health. The topic areas were selected from a pilot study of the first 10 interviews and included topics mentioned by these doctors, with others added by the author (some because they seem to be important to a paediatrician, others as distractors). The full set of 25 topics is shown in the Appendix.

The doctors were asked to rank each topic on a scale of 1 to 5 , according firstly to its importance in their present work and secondly to its deficiency or 
otherwise in their undergraduate teaching. (A score of 1 indicated not important or deficient, a score of 5 highly important or very deficient.)

The doctors were also asked for any general comments on their undergraduate teaching and finally to rank specific recommendations on teaching on a scale of 1 to 5 (a score of 1 indicated not important, a score of 5 very important.) Details of school of qualification and postgraduate experience were obtained from each doctor.

A subsample of 15 doctors were re-interviewed nine months later to determine whether increased

Table 1 Items ranked most highly for their importance in practice (all doctors)

\footnotetext{
Examination of children-general

Examination of cars*

Handling of babies

History taking

Diagnosis of minor ailments

Management of minor ailments

Prescribing in children

Practical aspects of immunisation
}

${ }^{*}$ Received high overall ranking for deficiency.

Table 2 Items ranked most highly for their deficiency in undergraduate teaching (all doctors)

Diagnosis of minor ailments*

Management of minor ailments*

Counselling of parentst

Management of children in trouble with police

Management of educational implications of illness:

Use of home remediest

Health education

Role of community agencies in child healtht

*Received high overall ranking for importance.

$\doteqdot$ High ranking for importance from trainee general practitioners only experience affected their view of paediatric priorities.

\section{Results}

Twenty five $(47 \%)$ of the 53 doctors were Dundee graduates, $11(21 \%)$ were graduates of other Scottish universities, and only four $(8 \%)$ were graduates of English medical schools, so that our results must reflect teaching in Dundee and may not be applicable to graduates of other medical schools. Forty $(75 \%)$ had graduated within the last five years $(11$ $(20 \%)$ within two years) and were therefore likely to remember their undergraduate years in a reasonably reliable way. Just over half had previous paediatric experience that might influence their judgment of the work in their present post.

Table 1 ranks the top eight topics according to the doctors' views of their importance and Table 2 the top eight according to doctors' views of their deficiency. The only items that occurred in both lists were the diagnosis and management of 'minor ailments' in children. Table 1 would contain the same items if the group of general practitioners were considered separately, though the order would be slightly different, as would Table 2 , with the addition of the examination of ears eighth equal.

The results of the re-interview for the items that were ranked most importantly by the whole group are shown in Table 3 . In most cases there was little difference in rating at the second interview. Only the items 'time off school' and 'health education' were ranked differently in importance, while the items 'examination of ears', 'diagnosis of minor ailments', and 'time off school' were ranked differently according to their deficiency in the doctors' undergraduate teaching. The recommendations

Table 3 Comparison of results of initial and repeat questionnaires (answered by 53 and 15 doctors, respectively)

\begin{tabular}{|c|c|c|c|c|c|}
\hline \multirow[t]{2}{*}{ Item no } & \multirow[t]{2}{*}{ Item title } & \multicolumn{2}{|c|}{$\begin{array}{l}\text { Importance in } \\
\text { present work }\end{array}$} & \multicolumn{2}{|c|}{$\begin{array}{l}\text { Deficiency in } \\
\text { undergraduate training }\end{array}$} \\
\hline & & Initial & Repeat & Initial & Repeat \\
\hline 3 & Handling of babies & $4 \cdot 16$ & $4 \cdot 13$ & 3.03 & $2 \cdot 93$ \\
\hline 4 & Examination of ears & $4 \cdot 35$ & $4 \cdot 8$ & $3 \cdot 17^{*}$ & $2 \cdot 47^{*}$ \\
\hline 6 & Counselling & $3 \cdot 36$ & 3.8 & $3 \cdot 77$ & $3 \cdot 87$ \\
\hline 7 & Minor ailments (diagnosis) & 4.47 & $4 \cdot 66$ & $3 \cdot 5^{*}$ & $2 \cdot 8^{*}$ \\
\hline 8 & Minor ailments (management) & $4 \cdot 35$ & $4 \cdot 66$ & $3 \cdot 57$ & 3.4 \\
\hline 10 & Feeding problems & $3 \cdot 81$ & 3.87 & 3.04 & $2 \cdot 8$ \\
\hline 12 & Prescribing & $4 \cdot 33$ & 4.4 & $2 \cdot 94$ & $2 \cdot 53$ \\
\hline 19 & Time off school & $3 \cdot 65^{*}$ & $4 \cdot 33^{*}$ & $3 \cdot 51^{*}$ & $4 \cdot 27^{*}$ \\
\hline 20) & Children and the law & $2 \cdot 35$ & $2 \cdot 33$ & $4 \cdot 04$ & $4 \cdot 4$ \\
\hline 22 & Health education & $3 \cdot 58^{*}$ & $4 \cdot 27^{*}$ & $3 \cdot 31$ & $3 \cdot 2$ \\
\hline 23 & Home remedies & $3 \cdot 19$ & 3.73 & $3 \cdot 54$ & $4 \cdot 0$ \\
\hline
\end{tabular}

Items were ranked on a scale of 1 to 5 according to their importance in current work ( $1=$ not important, $5=$ highly important) and deficiency in undergraduate training $(1=$ not deficient, $5=$ very deficient $)$

${ }^{*} p<0 \cdot 05$; all other differences between ratings were not significant. 


\section{Waterston}

Table 4 Recommendations most highly rated by doctors

\begin{tabular}{|c|c|c|c|c|}
\hline & \multirow[t]{2}{*}{ Recommendation } & \multicolumn{3}{|c|}{ Rating group } \\
\hline & & $\begin{array}{l}\text { Senior } \\
\text { house } \\
\text { officers }\end{array}$ & $\begin{array}{l}\text { Traine' } \\
\text { general } \\
\text { practitoners }\end{array}$ & Total \\
\hline 1 & $\begin{array}{l}\text { There ought to be more emphasis on the diagnosis and management } \\
\text { of 'minor ailments' in children }\end{array}$ & $4 \cdot 3$ & $4 \cdot 5$ & $4 \cdot 4$ \\
\hline 2 & This would be taught best by lectures & $2 \cdot 6$ & $2 \cdot 5$ & $2 \cdot 5$ \\
\hline 3 & This would be taught best by attachments to general practice & 3.9 & 4.() & 4.1) \\
\hline 4 & $\begin{array}{l}\text { Students should be more practically involved in the ward } \\
\text { in taking histories and examining children and have some } \\
\text { degree of responsibility for their patients }\end{array}$ & $4 \cdot 3$ & $4 \cdot 3$ & $4 \cdot 3$ \\
\hline 5 & $\begin{array}{l}\text { In view of the number of students. this could only be achieved } \\
\text { by a much greater use of peripheral hospitals for } \\
\text { student attachments }\end{array}$ & $3 \cdot 8$ & 3.9 & 3.9 \\
\hline 6 & $\begin{array}{l}\text { Students should visit patients in their homes to } \\
\text { appreciate the importance of the environment in health }\end{array}$ & $3 \cdot 2$ & $3 \cdot 8$ & $3 \cdot 5$ \\
\hline 7 & $\begin{array}{l}\text { Students should have longer attachments in the community so that they } \\
\text { see children in a more natural environment-for example. at nursery } \\
\text { schools and clinics }\end{array}$ & $3 \cdot 3$ & 3.9 & 3.6 \\
\hline 8 & $\begin{array}{l}\text { Students should spend more time in specialist areas. such as } \\
\text { paediatric cardiology and paediatric neurology }\end{array}$ & $2 \cdot 5$ & $2 \cdot()$ & $2 \cdot 2$ \\
\hline
\end{tabular}

Doctors were asked to rank recommendations on a scalc of 1 to 5 (1=not important, $5=$ highly important $)$.

\section{Appendix}

Full questionnaire and ratings by 23 senior house officers (SHO) and 30 trainee general practitioners (GP)

\begin{tabular}{|c|c|c|c|c|c|c|c|}
\hline \multirow{2}{*}{$\begin{array}{l}\text { Item } \\
\text { no }\end{array}$} & \multirow[t]{2}{*}{ Item title } & \multicolumn{3}{|c|}{ Importance in present work } & \multicolumn{3}{|c|}{ Deficiency in undergraduate training } \\
\hline & & $\mathrm{SHO}$ & GP & Total & $\mathrm{SHO}$ & GP & Total \\
\hline 1 & History taking in children & 4.6 & 4.6 & $4 \cdot 6$ & 2.1) & 2.0) & $2 \cdot 1)$ \\
\hline \multirow[t]{2}{*}{2} & Examination of children in & & & & & & \\
\hline & general & $4 \cdot 8$ & $4 \cdot 6$ & 4.7 & $2 \cdot 2$ & $2 \cdot 4$ & $2 \cdot 3$ \\
\hline 3 & Handling of babies & 4.0 & $4 \cdot 2$ & $4 \cdot 1$ & $3 \cdot 2$ & $2 \cdot 8$ & 3.0 \\
\hline 4 & Examination of ears & 4.0) & $4 \cdot 6$ & $4 \cdot 3$ & $3 \cdot 1$ & $3 \cdot 2$ & $3 \cdot 2$ \\
\hline 5 & Developmental assessment in practice & $3 \cdot 6$ & 3.2 & 3.4 & $2 \cdot 6$ & 2.9 & $2 \cdot 8$ \\
\hline \multirow[t]{2}{*}{6} & Counselling of parents of & & & & & & \\
\hline & children with chronic diseases & $3 \cdot 6$ & $3 \cdot 3$ & $3 \cdot 4$ & 3.8 & $3 \cdot 5$ & 3.7 \\
\hline \multirow[t]{2}{*}{7} & $\begin{array}{l}\text { Diagnosis of 'minor ailments'-for example, } \\
\text { catarrh, glue ear, knock knees. }\end{array}$ & & & & & & \\
\hline & rashes. crying at night & 4.4 & $4 \cdot 7$ & $4 \cdot 5$ & 4.5 & $3 \cdot 3$ & 3.5 \\
\hline 8 & Management of 'minor ailments' & 3.9 & $4 \cdot 6$ & $4 \cdot 3$ & 3.7 & $3 \cdot 2$ & 3.5 \\
\hline \multirow[t]{2}{*}{9} & Feeding techniques in practice. & & & & & & \\
\hline & including breast feeding & 3.0 & $3 \cdot 7$ & $3 \cdot 4$ & $3 \cdot 2$ & 2.9 & 3.0 \\
\hline 10 & $\begin{array}{l}\text { Feeding problems, including } \\
\text { colic and constipation }\end{array}$ & 3.7 & $4 \cdot 1$ & 3.8 & 3.3 & 2,7 & 3.0 \\
\hline \multirow{3}{*}{$\begin{array}{l}11 \\
12\end{array}$} & $\begin{array}{l}\text { colic and constipation } \\
\text { Immunisation. practical aspects }\end{array}$ & $3 \cdot 7$ & 4.5 & 4.0) & 2.4 & $2 \cdot()$ & $\begin{array}{l}3 \cdot 11 \\
2 \cdot 2\end{array}$ \\
\hline & Prescribing in children, especially use & & & & & & \\
\hline & of different formulations in practice & $4 \cdot 2$ & $4 \cdot 4$ & $4 \cdot 3$ & $3 \cdot 1$ & $2 \cdot 8$ & 2.9 \\
\hline 13 & Psychiatric history taking & $2 \cdot 1$ & 3.0 & 2.6 & 3.5 & 3.0 & $3 \cdot 2$ \\
\hline 14 & Management of behavioural problems & $2 \cdot 6$ & 3.7 & $3 \cdot 2$ & $3 \cdot 2$ & 2.9 & $3 \cdot 1$ \\
\hline 15 & Examination of newborn & 3.0 & $3 \cdot 3$ & $3 \cdot 2$ & $2 \cdot 2$ & $2 \cdot 3$ & $2 \cdot 3$ \\
\hline 16 & Management of common newborn problems & 3.0 & 3.6 & $3 \cdot 3$ & 2.9 & $2 \cdot 3$ & $2 \cdot 6$ \\
\hline \multirow[t]{2}{*}{17} & Management of growth and development & & & & & & \\
\hline & disorders-for example, short stature & $2 \cdot 4$ & $2 \cdot 7$ & $2 \cdot 6$ & $2 \cdot 5$ & $2 \cdot 6$ & $2 \cdot 6$ \\
\hline 18 & Management of children with handicap & $2 \cdot 7$ & 3.0 & $2 \cdot 8$ & $2 \cdot 8$ & $2 \cdot 8$ & $2 \cdot 8$ \\
\hline & 'How long should children be off school?' & $2 \cdot 9$ & 4.1 & $3 \cdot 6$ & $3 \cdot 8$ & $3 \cdot 3$ & 3.5 \\
\hline \multirow[t]{2}{*}{20} & Children in trouble with & & & & & & \\
\hline & police_procedures & $2 \cdot 4$ & $2 \cdot 3$ & $2 \cdot 3$ & $4 \cdot 2$ & 3.7 & 4.0) \\
\hline 21 & $\begin{array}{l}\text { Role of community agencies - for } \\
\text { example. school medical service }\end{array}$ & $2 \cdot 4$ & 3.4 & 2.9 & $3 \cdot 2$ & $3 \cdot 3$ & $3 \cdot 2$ \\
\hline 22 & Health education in practice & 2.9 & $4 \cdot 1$ & 3.6 & $3 \cdot 2$ & $3 \cdot 4$ & $3 \cdot 3$ \\
\hline 23 & Relation of environment to health & $2 \cdot 7$ & 3.6 & $3 \cdot 2$ & $2 \cdot 6$ & 3.0 & $2 \cdot 8$ \\
\hline 24 & Investigation of hypothyroidism & $2 \cdot 7$ & $2 \cdot 4$ & 2.5 & $2 \cdot 3$ & $2 \cdot 1$ & $2 \cdot 2$ \\
\hline 25 & Use of home remedies in children & $2 \cdot 6$ & 3.6 & $3 \cdot 2$ & 3.5 & 3.5 & 3.5 \\
\hline
\end{tabular}

Items were ranked on a scale of 1 to 5 according to their importance in current work ( $1=$ not important. $5=$ highly important $)$ and deficiency in undergraduate training $(1=$ not deficient, $5=$ very deficient $)$ 
most highly rated by most doctors $(3 \cdot 5$ or over) are shown in Table 4. Almost all considered that there ought to have been more emphasis in their undergraduate teaching on the diagnosis and management of 'minor ailments' in children.

A detailed breakdown of the ratings in each area is given in the Appendix.

\section{Discussion}

This study highlights certain areas of clinical practice that doctors who were entering a particular field of practice for the first time thought to be of particular importance yet that had been deficient in their undergraduate teaching. The method of obtaining the information may be criticised on the following grounds:

(1) The doctors were not sufficiently experienced to be able to assess reliably what is important in clinical practice. This may be true and it is certainly likely that additional items would be accorded greater importance by more experienced doctors. Attention must be paid, however, to the items that the doctors considered to be important for them.

(2) The doctors' memories of their undergraduate teaching may be hazy and influenced by intervening experience. Also the topic that they considered deficient may have been taught sufficiently, but they did not remember it because they were unaware of its importance at the time. It is true that certain subjects are only recognised to be important when their relevance to clinical practice is perceived. This is more a criticism of the method of teaching than of the curriculum as a whole.

(3) The doctors' prioritisation of different topics may not be consistent. Thus if they had been asked the same question on a different day a different ranking might have been given to the various items. The later interviews, which supported the earlier views of priorities, discounts this criticism.

It is pleasing that deficiencies were not noted in the undergraduate teaching of history taking and the examination of children. A more objective study would be required to assess the true proficiency of doctors in these crucial areas.

Topics of considerable clinical importance, however, such as the management of common ailments in childhood, were thought by the doctors to be insufficiently emphasised in their paediatric undergraduate course. Yet as Knox pointed out, such conditions (the 'trivia' of general practice) are of considerable importance for at least three reasons: they may represent the early stages of serious disease, they are of great concern to parents, and they are often symptoms of wider family problems that require elucidation. ${ }^{3}$ They also require specific management that may not be self evident.

Who should teach about this area, which is not easy to define as it relates more to symptoms than to diseases? Many would say general practitioners, as it is in the surgery rather than the hospital that children with these conditions are mainly seen. Logically, however, all teaching about children should be coordinated by a child health department, and to separate primary care aspects would be divisive in this era of integration. A move towards problem based teaching would help in emphasising presenting symptoms rather than diseases, and this should be encouraged. It might also be said that these topics should be taught in postgraduate rather than undergraduate education, as part of vocational training for general practitioners. It would seem important, however, for anyone dealing with children to be proficient in symptom management, and if the subject is important to a doctor this fact should be recognised in undergraduate teaching.

It must be accepted that this type of study does not provide an objective assessment of the content of undergraduate teaching as no analysis was made of the doctors' skills in the different areas. It is quite possible, for instance, that their history taking skills were inadequate but that they did not recognise this failing. A behavioural observation study would be required to provide such follow up information, which is much needed in the evaluation of undergraduate curricula.

I am grateful to Maureen Anderson, who as a research assistant carried out most of the interviews. and to the Leverhulme Trust, whose grant funded the study.

\section{References}

${ }^{1}$ Meadow SR. Students' assessment of paediatric teaching and their opinions 7 years later. Arch Dis Child 1978:53:653-5.

2 Dunn WR, Hamilton DD. The determination of priorities in the postgraduate education of pharmacists. Report of the Pharmaceutical Society of Great Britain. Edinburgh: Pharmaceutical Society of Great Britain, 1985.

${ }^{3}$ Knox JDE. Triage, trivia and treatment. $\mathrm{Br}$ Med $\mathrm{J}$ 1984;288:1504-6.

Correspondence to $\operatorname{Dr} \mathrm{T}$ Waterston, Community Child Health, Newcastle General Hospital, Newcastle upon Tyne NE4 6BE, England.

Received 11 December 1986 